China Perspectives

57 | january - february 2005

Varia

\title{
Recent Trends in Chinese Labour Issues-Signs of Change
}

Anita Chan

\section{(2) OpenEdition}

\section{Journals}

Édition électronique

URL : http://journals.openedition.org/chinaperspectives/1115

DOI : 10.4000/chinaperspectives. 1115

ISSN : 1996-4617

Éditeur

Centre d'étude français sur la Chine contemporaine

\section{Édition imprimée}

Date de publication : 15 février 2005

ISSN : 2070-3449

Référence électronique

Anita Chan, «Recent Trends in Chinese Labour Issues-Signs of Change», China Perspectives [En ligne], 57 | january - february 2005, mis en ligne le 01 février 2008, consulté le 21 décembre 2020. URL : http://journals.openedition.org/chinaperspectives/1115; DOI : https://doi.org/10.4000/ chinaperspectives. 1115

Ce document a été généré automatiquement le 21 décembre 2020.

(C) All rights reserved 


\title{
Recent Trends in Chinese Labour Issues-Signs of Change
}

\author{
Anita Chan
}

Migrant workers withdrawing their labour

1 Newspaper reports about Chinese cities and towns experiencing a shortage of labour began appearing in $2003^{2}$, and again in March 2004 following Chinese New Year ${ }^{3}$. By mid-2004 a spate of reports surfaced in the press indicating that the problem had reached crisis level in the coastal industrial regions, particularly in Guangdong province-and Dongguan city, where Taiwanese factories are concentrated, reportedly the most affected. The shortage was first noticed when fewer migrants from the countryside arrived to look for jobs after Chinese New Year in February. But it made headline news when the busy production season set in around June, when massive amounts of overtime work normally begin. Chinese newspaper photos showed factories setting up roadside stalls trying to recruit workers. Teeming crowds of migrants no longer jostled before factory gates for a job. In December 2004 a garment factory manager in Dongguan claimed to me that $80 \%$ to $90 \%$ of the factories could not hire enough labour and so had to scale down production capacity. He wanted, he said, to hire at least another hundred workers. He was about to approach the factory owner to ask that funds be allocated to improve conditions so that he could attract more workers after the 2005 Chinese New Year.

2 Media reports on the labour shortages have offered a variety of explanations, all of which are valid: poor working conditions, low wages, decreases in wages, wages in arrears, various forms of abuses, improving economic conditions in the rural sector due to recent higher prices for agricultural produce and lower agricultural taxes, etc. Above all, the press recognises that pay and work conditions have deteriorated so much that migrants are no longer interested in working away from their villages, particularly in Guangdong. Weighing the value of their labour against the pay offered, the investment involved in making the journey to look for work and the risk of not being paid or being injured in an industrial accident, they prefer to stay at home. In this sense, the free labour market in China is indeed functioning freely. But which of these contributing 
factors finally broke the camel's back? My own belief is that against declining wage levels and mounting problem of unpaid wages, people feel that migrating to look for a factory job does not pay ${ }^{4}$.

In real terms migrant workforce incomes have been progressively falling 5 . The Ministry of Labour and Social Security recently recognised this in an official release stating, "Studies show the salary of a migrant worker in the Pearl River Delta area has grown by a mere 68 yuan (US\$8.2) over the last 12 years, far behind the increase in living expenses, and in real terms, wages are declining"6, one can add, by a large margin. The wages have also become irregular. Labour flexibility has become so prevalent that when there is no work, workers sometimes have no income; and during busy periods, a vast amount of overtime is often imposed in violation of national laws-at its worst, up to one hundred hours or more a week, especially at some of the private factories that produce for export.

4 Just as bad, the amount of unpaid wages has been increasing annually. I started collecting Chinese newspaper clippings on this problem in the mid-1990s. At that time, reports on migrant workers not getting paid were regarded as isolated incidents ${ }^{7}$. but as the years went by the problem became endemic. Even local governments began to see a need to intervene. Every year just before Chinese New Year, local governments would launch "chasing after wage-arrears campaigns" (zhuihui qianxin yundong) and then would proudly announce xxx million yuan had been "chased back" for the workers. The amounts soared year after year ${ }^{8}$. In Guangdong province the amounts "chased back" in 1995, 1997 and 1998 were 21 million yuan, 1.5 billion yuan and 5.6 billion yuan respectively.

5 But these amounts could only be the tip of the iceberg of the total amount of unpaid wages, since many cases were not reported. Even when reported and dealt with by the authorities, factories sometimes have simply refused to comply. According to one survey, $72.5 \%$ of migrants have suffered from varying degrees of wage defaults. There is little legal protection against unpaid wages ${ }^{9}$. The formal procedures taken by Labour Inspection Departments when demanding that a factory pay unpaid wages are so lax that management can easily default by closing down the factory and opening another ${ }^{10}$. The situation has become so serious that one Chinese newspaper report has declared "Wage arrears have become a "custom""11; and another opined that it needs "a strong dose of medicine"12 to cure it.

6 The national figures on the construction industry can serve as a guide to the enormity of the problem. The estimates on unpaid wages in the state-regulated construction sector in the past few years have been 278 billion yuan in 2001, 336.5 billion yuan for $2002^{13}$, and 367 billion yuan for 2004 up to August ${ }^{14}$. Yet these are figures for only one part of one industrial sector comprising 38 million migrant workers ${ }^{15}$. What about the manufacturing sector, in particular the export-oriented sector, which employs a larger labour force? The reports about migrant workers in the export-oriented factories being owed wages indicates the problem is possibly even more serious there, and the cumulative amount of unpaid wages higher.

7 In past years, the authorities did not find a solution to the problem of declining wages and unpaid wages. The best they could do was to help a minority of lucky workers to "chase back" wages before Chinese New Year. Today, it looks like the migrant workers have found their own solution-by withdrawing their labour and staying at home in the villages, causing a crisis of a "shortage of migrant workers" (mingong huang). Unable 
to collectively bargain at the workplace, the rural population of China, without organising themselves, are engaging in a form of spontaneous collective action and initiating changes in China's macro-labour market. In this sense, from the poor work conditions something positive is being generated.

The settlement of workers' grievances through legal channels

A second type of change on the labour front relates to workers' growing awareness and use of the legal arena. The three main labour-related laws-the Enterprise Law passed in 1988, the Trade Union Law of 1992 and the Labour Law of 1994-have provided a legal framework for the development of industrial relations at a time of economic restructuring and the transition of many state enterprises to private ownership. They all contain clauses that potentially could empower workers through a number of important labour protection articles, though without the freedom to organise independent trade unions. Under the Trade Union Law, work stoppages and slowdowns are deemed to be legal, and one of the core international labour rights, the right of collective bargaining, is guaranteed by the Labour Law ${ }^{16}$. The new laws have stipulated a maximum number of work hours and a minimum age to enter the work force. They have established industrial labour dispute procedures, and include clauses on the right to a democratically elected workplace union-statutes on a par with international standards. In fact, at least one provision in Chinese law surpasses international labour standards: a stipulation that state-owned and collectively-owned enterprises are to contain a Staff and Workers Representative Congress, which has been given the legal power (on paper, at least) to supervise management and to co-determine or to veto certain management decisions ${ }^{17}$.

Notwithstanding this flurry of commendable legislative activity on behalf of employees' rights, it is clear that there has been a relative lack of enforcement of the labour laws and that there are major violations of workers' rights, even in some state-owned factories. Workers in both the state and non-state sectors are laid off with impunity, for instance, without regard to the legal procedures for doing so. "Unfair dismissal" does not even enter the Chinese labour lexicon. But workers have begun to protest.

Reactive legal protest activities

10 As economic restructuring steamed ahead at a rapid pace in the 1990s, and as labour violations became more serious and widespread, worker protests had by the mid-1990s increased in scale and frequency. Much of this has been documented in the Chinese press and by the international media and Western scholars. The new labour laws also had their effect. The number of labour disputes that went to arbitration under the provisions of the labour laws leaped, from 19,000 in 1994 to 184,000 in $2002^{18}$. The prolabour clauses that had been inserted into the laws helped to channel some grievances into legal procedural action. The laws not only have provided a platform for this, but workers' awareness of their legal rights also has been on the rise.

11 The majority of these cases involve serious labour abuses, such as owing workers wages in arrears (both in state and non-state enterprises), state workers being laid off, irregularity in pension payments, excessively long work hours, a lack of compensation for industrial injuries, and contraction of work-related diseases. According to one study, the less educated workers tend to take their grievances to the Visits and Letters Offices that are run by the cities' Labour Bureaus, People's Congresses or Party organs, while the more educated and skilled employees more often take their cases to legal arbitration ${ }^{19}$. Either way, these are reactive claims, employing spaces provided by the 
legal system to redress injustices. They are not proactive claims to rights that are collective in nature, such as laying legal claims against management for refusing to collectively bargain, or against trade union officials for not protecting their rights ${ }^{20}$. In fact, the legal channels may even serve to avert a crisis situation where workers might actively seek to set up alternative trade unions or engage in mass protest, the reason in fact behind the government's policy to regulate industrial relations through legal channels.

The passage of the new laws has also led to a substantial number of lawyers and paralegals offering services to workers who seek compensation through law suits for industrial injuries and occupational diseases. Some of the lawyers operate from within the legal aid centres of university law schools or the trade unions, ${ }^{21}$ while others have started their own private practices. The suits seeking compensation are becoming increasingly aggressive, despite their reactive nature, and the government is willing to grant more space to such court actions. Nonetheless, the litigation is a long drawn-out process, and most ordinary workers and migrant workers can ill afford the time or money to pursue this channel.

When the legal channels fail to resolve problems, protest activities escalate into collective street action. In the state sector, workers continue to hark back to "collective memories of state socialism" 22 , and are often motivated by a subsistence crisis caused by managerial corruption ${ }^{23}$. These tend to be workers who have been laid off or are in the midst of being laid off or forced into early retirement. Workers still in employment do not normally join in ${ }^{24}$.

Participatory rights at enterprise level

Another type of phenomenon that warrants attention are the Staff and Workers Representative Congresses (SWRCs, zhigong daibiao dahui). These first appeared in the 1950s, were revived a few years before the industrial reforms began in the mid-1980s, and were used during the following years by at least some workplace unions to counteract the rising power of factory managers ${ }^{25}$. Although workers in state and collective enterprises are supposedly empowered to participate in this so-called "democratic management", the attempt has not met with much success ${ }^{26}$. In many enterprises they are never convened, and in some others they are controlled entirely by management. Yet the Congresses have not been entirely useless. SWRCs, though weak, sometimes serve to check total management domination. In some cases, a state enterprise's directors may even prefer to enlist the enterprise Congress's involvement when matters arise that of considerable concern to the workforce ${ }^{27}$. In the Chinese press, particularly in newspapers published by the Chinese trade union structure, there have also been reports of cases where workers faced with unemployment and disentitlement of benefits or efforts to privatise the firm by corrupt managers and local officials have, against the odds, taken matters into their own hands and convened their enterprise Staff and Workers Congress to fight off the attempts, in some cases successfully sacking the managers ${ }^{28}$.

The union federation subjected to new pressures

Although Chinese labour laws do not allow truly independent trade unions, they contain provisions for internal democracy in the official enterprise-level trade union branches. In a one-party state that controls the appointment of union officials, to speak of exercising internal democracy may seem an oxymoron. But after a decade and a half of competitive elections for village leaders, there is a widespread awareness in China 
regarding elections. Nonetheless, despite the provisions in the labour laws, as yet there has been no surge of suggestions from Chinese academics or by the more adventurous wings of the Chinese press that, like farmers, workers should be allowed to elect their own representatives. Over the past three years the biggest push for managementlabour dialogue and even elections at the workplace have come from outside China.

The Corporate Social Responsibility debate

The concept of Corporate Social Responsibility was introduced into China in the mid-1990s. It originated with the anti-sweatshop movement in the developed countries, which accused brand-name Western corporations of turning a blind eye to dangerous, inhumane conditions in the factories around the world that make merchandise for them under contract. To ward off the criticism, many Western companies have adopted "corporate codes of conduct", demanding compliance with a minimum set of standards by their sub-contractors ${ }^{29}$. Many have hired corps of monitors and auditors to police the subcontractors' factories, threatening monetary penalties or cancelling orders if factory managements violate their codes ${ }^{30}$.

The movement's impact on China became visible by the end of the 1990s. In the midnineties, when I visited Taiwanese and Hong Kong-owned supplier factories in Guangdong and Fujian provinces, owners and managers mentioned nothing of pressures from the Western corporations. But beginning around 2000, some complained bitterly about such pressures mounting. As a consequence, working conditions have improved at some of the larger factories, though excessive overtime continues to remain a serious problem at practically all of these factories.

Most of the subcontractors, though, quietly sought to circumvent the Western corporations' codes of conduct. They gradually learned to bribe or trick the monitors, developing elaborate double book-keeping, and coaching workers on what to say to monitors. In turn, many of the Western corporations have moved on to a new stage: paying trainers to go into the subcontractors' factories to educate workers in their labour rights. There are no official statistics, but based on the large number of organisations, including the official All-China Women's Federation in Guangdong, that have been hired to provide "worker training", it appears that a fair portion of the more than 10 million migrant factory workers in South China have had at least a couple of hours of this awareness-raising exercise.

19 The Guangdong government and provincial trade union ignored the monitoring activities for some years, but more recently have felt a need to learn more about the impact of problematic labour standards and industrial relations on the investment climate. They have invited experts to hold workshops on the anti-sweatshop movement, corporate social responsibility, and the efforts to monitor supplier firms ${ }^{31}$. Aware that Asian countries such as Cambodia, Vietnam and Thailand ${ }^{32}$ are willing to accept the corporate social responsibility movement in the hope of attracting additional foreign investment, the Guangdong government began to feel obliged to come up with a positive position on this.

Within the past year, the national media was also onto the issue. 2004, for instance, saw a flood of reports and discussions about the New York-based multi-stakeholder NGO Social Accountability International (SAI), which issues SA8000 licences to manufacturing facilities that comply with the labour standards set by the organisation. A heated debate in the Chinese news media over whether SA8000 is an instrument to protect the rights of Chinese workers ${ }^{33}$ or a stick wielded on behalf of Western 
"protectionism" suddenly brought the issue of corporate social responsibility into the open. Those in China who want to see the labour conditions of migrant workers improve welcome SAI's efforts to oversee the SA8000 standard, while those who do not, for fear of the loss of China's "competitive edge", see SA8000 as an unwanted Western intervention ${ }^{34}$. Some Chinese reporters, confused about the issue, wrongly reported that SA8000 is a US government ploy.

21 The government in Peking has been of mixed minds on this issue of corporate social responsibility and internationally supervised labour standards. The Chinese State Council's Development Research Centre agreed to co-sponsor, with the Organisation of Economic Co-operation and Development (OECD), an international conference on "Socially Responsible Investment in China and North-East Asia-The Role of the OECD Guidelines for Multinational Enterprises" ${ }^{35}$. The conference was scheduled to convene in Peking in mid-December 2004 and was to be attended by government, corporate and trade union delegates from around the world. But there was strong opposition to the conference within the Chinese government, and just ten days before it was to open the government abruptly called it off.

John Sweeney, president of the American trade union federation, the AFL-CIO, was scheduled to head a high-powered delegation from the International Confederation of Free Trade Unions (ICFTU), containing the heads of several other Western trade union federations, to the Peking conference. The ICFTU, mired in a cold-war mentality, has refused to let the Chinese trade union federation, the ACFTU, into the international trade-union club. But this time there were signs of a rapprochement; the delegation had agreed to engage in high-level meetings with the ACFTU following the OECD conference. The ACFTU has been eager to be welcomed into the fold of the "brotherhood" of the international trade union movement, and the meeting in Peking would be a breakthrough. Such hopes were dashed by the Chinese government's sudden announcement. On top of cancelling the OECD conference, it also cancelled all of the delegates' visas to China, making it impossible for the ICFTU delegates to visit China even as private individuals, let alone meet with their Chinese counterparts. The decisions to cancel the OECD conference and the visas were taken at a level far higher than the ACFTU, and appears to have taken its leadership by surprise.

A second incident in early December 2004 helps to put the Chinese government's sudden decision into context. The British Consulate in Guangzhou held a conference in a hotel in Shenzhen-hub of southern China's export drive-on "The UK and the Greater Pearl River Delta: Developing Corporate Social Responsibility Together". At the conference Chen Ying, the Deputy Director General of China's Enterprise Confederation (CEC, Zhongguo qiye lianhe), dropped a bombshell. CEC is China's major employers association and represents China's employers in the ILO. Though the organisation was only set up in the 1980s, and is still very much under the wing of the Chinese government, the confidence of its mission is embodied in Ms Chen. She told the audience in no uncertain terms that foreign corporations should abide by the Chinese labour laws, but because the laws are not yet perfected the CEC, with twenty government departments, was now developing its own standards for corporate social responsibility. The message: we Chinese are saying "no" to your foreign-imposed workplace standards. The OECD's guidelines are obviously among the unwanted foreign standards.

The new push to unionise foreign-run enterprises 
factories should have freedom of association, not an easy aim to achieve in China. Some of the Western corporations that are the most serious in addressing this have initiated occupational health and safety committees or other forms of workers' representative committees. Reebok has gone further, and has successfully pressured three of its supplier factories, owned by Taiwanese and Hong Kong firms, to hold democratic trade union elections, respectively in 2001, 2002 ${ }^{40}$ and 2003. This has put pressure on other Western brand-name corporations ${ }^{41}$. For several years, the Chinese authorities and the ACFTU chose to remain neutral not just regarding the monitoring initiatives, but also with regard to enterprise-level elections. But in August 2003, a vice-president of the ACFTU made references in a speech that was carried by the media to the effect that foreigners should not intervene in Chinese trade union affairs ${ }^{42}$. Nonetheless, the elected union committees at the three Reebok suppliers remain in place.

Elsewhere, "direct elections" of workplace trade union chairs have occurred at several private enterprises in Guangdong and Zhejiang provinces, apparently as a result of regional union initiatives ${ }^{43}$. In Hangzhou, the capital city of Zhejiang, 310 factories reportedly held direct elections five years ago, though this was kept out of the Chinese news media until 200344. In September 2003 the ACFTU announced that it would promote such elections elsewhere in China within the next few years ${ }^{45}$. 

the corporate social responsibility movement and to the Reebok-inspired elections. Some internal ACFTU reports noted that several supplier factories had held direct elections after being pressed to comply with Western corporation codes of conduct. Thus, popularising "direct elections" could be the ACFTU strategy to forestall foreigners coming in to set up workers' committees. Whether such elections are truly democratic remains a question to be studied, as "direct" is not synonymous with "democratic". As shown by a number of studies of village elections, the format, nature and results of elections vary widely across China, yet, whatever the shortcomings, the researchers' overall consensus is that the elections have had a positive impact, often giving farmers some say in the running of their local communities ${ }^{46}$. Thus, the initiation of factory-level union elections in China, whether fully democratic or not, may gradually have the effect of giving workers more direct representation and a means to check the power of management in protection of their own rights.

The ILO tripartite structure

Another avenue that may instigate change in China's industrial relations involves the International Labour Organisation (ILO). As a member state, China needs to establish a tripartite peak body comprising representatives from a national labour union federation, a peak employers' association, and a government organ, in order to send delegates from the three groups to the ILO's annual meetings in Geneva. Whereas the ACFTU serves as China's peak union organisation, there was no peak employers' association, so in 1999 the China Enterprise Confederation (CEC) was set up to serve this function. Its membership consists largely of state-enterprise management. In the ILO tripartite model the three parties are supposed to be independent and strong enough to carry out a meaningful "social dialogue". To the extent that such a peak system evolves, this potentially works to diffuse the statist nature of China's corporatist arrangements. Today, the system is still embryonic: the ACFTU remains under the control of the Party-state, and the CEC is still under development ${ }^{47}$. Nevertheless, a National Tripartite Consultative Committee was set up in 2001, with similar committees at all administrative levels down to the rural townships. An ILO fact-finding commission found half a year after the tripartite committee's establishment that: "The tripartite system as presently constituted is unlikely to live up to the hopes placed in it both now and in the future... However, in all our interviews with trade union and employer representatives at municipal and national levels we found a clear commitment to developing the capacity of their respective organisations as independent representatives, able to articulate the interests, aspirations and grievances of their members within the system of social dialogue" ${ }^{48}$.

The fact-finding commission also noted that the "ACFTU has been the most active proponent of tripartite consultation as a means of protecting its members and maintaining social peace". As an independent observer who accompanied the twomember ILO commission in its investigations across China, I was impressed that officials from China's Ministry of Labour, which often sides with corporations in line with the government's pursuit of economic development, on two separate occasions remarked that the ACFTU is "powerful", as if the Ministry has difficulty cowing the ACFTU into accepting its decisions. This characterisation is in line with the assertive role the ACFTU has played in the national legislative process in helping to shape the content of China's labour laws. Thus, at the peak level the ACFTU appears to be 
successfully manoeuvring to make its voice heard and to attain greater bargaining power and at least a modicum of independence.

Anticipating the future

At the very top, as illustrated by the above incident, the ACFTU has tried to stake out its own position of labour representation as distinct from the state and employers. This is made easier by the backing of an external supporter, in this case the ILO, of which the Chinese government is a member state. The ACFTU has also continued to play an active role on the legislative front. The revision of the Labour Law passed in 2001 was due in part to its lobbying efforts. It is now participating in helping to draw up a revision of the Company Law to ensure that the Staff and Workers Representative Congress maintains its legal position in enterprises. The ACFTU's survival instincts tell it that unless it can represent the interests of the workers, it will become irrelevant.

The state enterprises traditionally all contain workplace unions and near-one hundred percent unionisation rates, but the number of state enterprises continues to fall. The ACFTU needs to maintain its membership and financial base by penetrating the nonstate enterprises that are increasing in numbers. But setting up workplace unions in domestic private enterprises and foreign-funded enterprises is not easy, given their owners' opposition, and very different from the traditional bureaucratic way of setting up branches in state-owned enterprises.

The aggressive stance taken by the ACFTU towards Wal-Mart is a new strategy that seems to have worked with the quiet backing of the state. The demonstration effect of this first-round victory may reverberate not only throughout China, but possibly have repercussions around the world. The ACFTU has thus successfully taken on the world's largest non-unionised corporation. The largest US trade union, which represents America's retail workers, the Service Employee International Union (SEIU), has been making overtures to the ACFTU to join hands in unionising Wal-Mart retail outlets ${ }^{49}$.

At lower levels, particularly at the district and workplace levels, the union officialdom has been overwhelmed by the power of local governments, capital and management. But pressure has been building for lower-level union officers to be more responsive to the needs of workers. The greatest pressure for the state-enterprise sector has come from workers laid off due to bankruptcy and changes in ownership, while the open exploitation of migrant workers confronts the unions with the embarrassing realisation that something needs to be done to remedy the abuses. As seen, the peaklevel union federation has been able to get clauses inserted into labour laws that provide workers with some legal leverage. Migrant workers have been able to use this to secure unpaid wages. The labour laws have spawned an active, growing group of lawyers and paralegals who specialise in representing aggrieved workers. These are embryonic, hopeful signs that enterprise-level union elections may become more frequent in future. In the state and collective sectors, the system of Staff and Workers Representative Congresses can sometimes be turned to. In what are often difficult times for blue-collar workers in China, there exist these various rays of hope in the labour relations arena. 


\section{NOTES}

1. An early version of this paper was delivered at the $40^{\text {th }}$ Anniversary Conference of the Universities Service Centre for Chinese Studies, held at the Chinese University of Hong Kong in January 2004. Part of this paper overlaps with an article published in New Labor Forum, Vol. 13, No. 3, Fall 2004, pp. 67-75.

2. Su Jie, "Bu gan dao Quanzhou dagong" (We do not dare not go to Quanzhou to work), Fazhi ribao (Legal Daily), June 23rd 2003.

3. Bao Xiaodong, "Laogong duanque" (Labour Shortage), Nanfang dushibao (Southern Metropolitan News), March 3rd 2004.

4. Chen Peihua (Anita Chan), "Zhongguo laodong de quanqiuhua ji dui guoji laogong de yingxiang" (Globalised Chinese Labor and Its Impact on International Labor), Pipan yu zaizao, Taiwan, No. 9, July 2004, pp. 21-27.

5. For an explanation of this decline in wages see Anita Chan, “A 'Race to the Bottom': Globalisation and China's Labour Standards", China Perspectives, No. 46, March-April 2003, pp. 41-49. Also see Liu Kaiming, Bianyuanren (Marginal People: Migrant Labour in South China), Peking, Xinhua chubanshe, 2003, p. 8 and pp. 145-160. According to one recent survey, migrants only make a third of the local populations' wages. He Buguai and Cheng Hengtao, "Di gongzi jingzai: laodongzhe mengyan" (Wages Racing to the Bottom: A Migrant Worker's Nightmare), Nanfang gongbao (Southern Labour News), July 29 th 2004.

6. Ministry of Labour and Social Security report, < http://www.molss.gov.cn/new/ 2004/0908a.htm>.

7. For example see, Fang Qiuxin, "Yuangong jiti shangfang tao gongzi, zhengfu juche gongdao ping minfen" (Employees Collectively Asked for Wages, the Government Adjudicate to Quell People's Wrath), Guangdong laodong bao (Guangdong Labour), March 1st 1999; Jian Chuanhai, "Qianxin 43 wan jing yizou liaozhi” (Ran away owing 430,000 yuan), Nanfang gongbao, July 4th 2001.

8. For example, Jiao Youlong, “Gongzifa neng baozheng gongzi anshi fafang ma?" (Can a Wage Law Guarantee that Wages Can be Paid on Time?), Zhongguo shehui bao (Chinese Society News), March 27th 2002.

9. “Laboring Over Workers' Rights", Beijing Review, Vol. 46, No. 52, December 25th 2003, pp. 46-47.

10. Lai Zhikai and Huang Siuzhen, "Tamen heshi buzai liuhan you liulei" (When Will they Stop Sweating and Crying?), Gongren ribao (Workers Daily), July 31st 2004.

11. Jian Chuanhai, "Tuoqian gongzi cheng le fengshu" (Owing Wages Has Become a 'Custom'), Nanfang gongbao, August 22nd 2001.

12. Mi Guoshen and Guo Yukwan, "Shenzhen mengyao zhi qianxin" (Shenzhen Uses Strong Medicine to Treat Wages Arrears), Zhongguo laodong baozhang bao (Chinese Labour Protection News), February 19th 2002.

13. Zhao Cheng and Qi Zhongxi, "Quanguo qingqiang gongjianzhan chujian chengxiao, qingli qianxin bushi 'guafeng"' (A Firm Battle to Clean Up Wages in Arrears Is Beginning to See Results, Clearing Up Wages in Arrears is Not 'Blowing Up A Storm'), Xinhuawan (New China Net), http://www.sina.com.cn, January 21st 2004. 
14. Press release from the State Council newsroom, August 26th 2004 <news.sohu.com>. This figure was provided by a deputy bureau chief of the construction bureau in a press conference opened to foreign journalists.

15. Ibid.

16. Bill Taylor, Chang Kai and Li Qi, Industrial Relations in China, Cheltenham, Edward Elgar, 2003, pp. 176-178 and pp. 182-206.

17. Enterprise Law, Chapter 5, Articles 49-54; 1992 Trade Union Law, Chapter 3, Article 16; 2001 Trade Union Law, Chapter 3, Article 19.

18. Fu Hualing \& D. W. Choy, "From Mediation to Adjudication: Settling Labor Disputes in China", China Rights Forum, No. 3, September 2004, pp. 17-22.

19. Isabelle Thireau and Hua Linshan, "The Moral Universe of Aggrieved Chinese Workers: Workers' Appeals to Arbitration Committees and Letters and Visits Offices", The China Journal, No. 50, July 2003, pp. 83-103.

20. The first lawsuit by an employee suing his trade union for not protecting his labour rights was described in Nanfang Zhoumo (Southern Weekly), September 4th 2003, p. A3.

21. Chen Feng, "Legal Mobilisation by the Chinese Trade Unions: The Case of Shanghai", The China Journal, No. 52, July 2004, pp. 27-45.

22. Ching Kwan Lee, "The 'Revenge of History' Collective Memories and Labor Protests in Northeast China", Ethnography, Vol. 1, No. 2, 2000, pp. 217-237; also Ching Kwan Lee, "Pathways of Labor Insurgency", in Elizabeth Perry and Mark Selden (eds.), Chinese Society: Change, Conflict and Resistance, New York, Routledge, 2000, pp. 41-61.

23. Feng Chen, "Subsistence Crises, Managerial Corruption and Labor Protests in China", The China Journal, No. 44, July 2000, pp. 41-63; Feng Chen, "Industrial Restructuring and Workers' Resistance in China”, Modern China, Vol. 29, No. 2, April 2003, pp. 237-262.

24. Personal communications with an independent Chinese researcher reveal that the massive workers' protests in 2002 at Daqing and at Liaoyang, Liaoning province, almost entirely involved laid off and retired workers. Western media reports and critics of China's suppression of the protests did not make this distinction.

25. Information on the role played by the Staff and Workers Representative Congress in the first half of the 1980s was collected for a collaborative research project with Peking academics that I am currently participating in regarding democratic workplace governance in China. Thanks are due to the Peking office of the Ford Foundation for funding the research.

26. Anita Chan, "Labor in Waiting: the International Trade Union Movement and China", New Labor Forum, Fall-Winter 2002, pp. 55-60.

27. On this latter type of case, see, e.g., Jonathan Unger and Anita Chan, “The Internal Politics of an Urban Chinese Work Community: A Case Study of Employee Influence on Decision-Making at a State Owned Factory", The China Journal, No. 52, July 2004, pp. $1-24$.

28. Zhu Xiaoyang and Anita Chan, "Zhili shidai zhigong liyi jizhong biaoda de zhiduhua qudao" (The Institutionalization of Channels for the Articulation of Workers' Interests), Kaifang shidai (Open Times), Guangzhou, February 2003, pp. 20-32.

29. Rainer Braun \& Judy Gearhart, "Who Should Code your Conduct? Trade Union and NGO Differences in the Fight for Workers' Rights", Development in Practice, Vol. 14, Nos. 1 \& 2, February 2004, pp. 183-196. 
30. See, e.g., Tan Shen and Liu Kaiming, Kuaguo gongsi de shehui zeren yu Zhongguo shehui (Corporate Social Responsibility and Chinese Society), Peking, Social Science Documentation Press, 2003.

31. Information provided in March 2004 by a PRC national who is working as a corporate code compliance officer for a UK firm and who in the past few years has tried very hard to get the Guangdong government and trade union to pay attention to the CSR movement.

32. Anita Chan and Wang Hongzen, "Raising Labor Standards, Corporate Social Responsibility and Missing Links-Vietnam and China Compared", presented the conference "The Labor of Reform: Employment, Workers' Rights, and Labor Law in China", University of Michigan, 21-22 March 2003. This has been published in Chinese as Wang Hongzen and Anita Chan, "States and the Anti-Sweatshop Movement: Evidence from China and Vietnam", Hong Kong Journal of Social Sciences, No. 26, Autumn/Winter 2003, pp. 103-126.

33. Jian Chuanhai, "SA8000: Laodongzhe de 'baohu san"' (SA8000: The Protective Umbrella of Laborers), Nanfang Gongbao, 7 April 2004.

34. For example, see Li Ying, “SA8000, xin de maoyi bilei?" (SA8000, a New Trade Barrier?), Nanfang Dushi bao, November 20th 2003.

35. The Guidelines were originally drawn up and signed by the OECD member countries. In June 2000 the Guidelines were thoroughly revised in a 67-page document signed by 33 countries. Further information on this can be accessed at www.oecd.org/ department, and the text of the guidelines at http://www.oecd.org/dataoecd/ 56/36/1922428.pdf.

36. Guo Li, "Wal-Mart Zhongguo 'gonghui weiji”" (Wal-Mart in China: “Trade Union's Crisis"), Ershiyi shiji jingji baodao (Twenty-first Century Economic News), 24 September 2003.

37. For example, "Wal-Mart chengdan buliao suoyou de zeren", (Wal-Mart Cannot Shoulder All the Responsibilities), Nanfang Zhoumo (Southern Weekly), 1 April 2004. 38. For a series of articles on this case, visit China Labor Watch's web site: www.chinalaborwatch.org.

39. "Wuoma huiying gonghui wenti-bisu keneng bu da" (Wal-Mart Responds to Trade Union Questions-Litigation Unlikely), Xinhuawang, November 11th 2004; "ACFTU to Help Wal-Mart Establish Trade Union," China Daily, November 27th 2004; Harold Meyerson, "Wal-Mart Loves Unions (In China)", Washington Post, December 1st 2004.

40. I was able to spend two weeks as an independent researcher at the factory that held trade-union elections in 2002, observing all of the speeches of the hundred-plus workers vying for election to the trade-union committee. On this election, see Alison Maitland, "Sewing a Seam of Worker Democracy in China", Financial Times, December 12th 2002; . Also see Doug Cahn \& Jill Tucker, “Worker Input Means Better Conditions in Factories", South China Morning Post, April 4th 2003. 41. Social Accountability International (SAI) is currently starting a pilot project to set up some forms of workplace workers' committees in three supplier factories.

42. Wang Jiaoping, "Direct Elections - Pushing Ahead in a Regularised Manner: ACFTU Deputy Chairman, Su Liqing's Response to Reports' Queries" (in Chinese), ACFTU handout, July 25th 2003.

43. This information comes from a private communication with a researcher within the trade union structure. 
44. Xie Chuanlei, Fu Jianfeng and Wang Jiajia, "Direct Trade Union Elections as a Form of New Labor-Capital Relation to Compete in the New Rules of the Game", Nanfang zhoumo, July 3rd 2003; Zhong Guodong, "Pushing Ahead with Direct Elections of Trade Union Chairs in Non-Publicly Owned Enterprises", Chinese Management News (in Chinese), March 17th 2003.

45. "China Trade Union to Allow Direct Election of Shop Leaders", Associated Press, September 26th 2003.

46. Liu Yawei, "Consequences of Villager Committee Elections in China. Better Local Governance or More Consolidation of State Power", China Perspectives, No. 31, September-October 2000, pp. 19-35; Günter Schubert, "Democracy Under One-Party Rule? A Fresh Look at Direct Village and Township Elections in the PRC," China Perspectives, No. 46, March-April 2003, pp. 15-25.

47. Simon Clarke and Chang-hee Lee, "The Significance of Tripartite Consultation in China", Asia Pacific Business Review, Vol. 9, No. 2, Winter 2002, pp. 61-80.

48. Ibid., pp. 77-78.

49. An SEIU delegation that I participated in, and headed by the union's president, Andy Stern, was in Peking in early December 2004, among other things to discuss this issue with the ACFTU.

\section{RÉSUMÉS}

In the Western press, there regularly have been reports about the plight of Chinese paid a pittance for working long hours making products for export ${ }^{1}$. The reports are accurate, and in fact, in a great many factories labour standards have continued to decline. But there are new developments in the labour arena that herald change.

The formerly vast pool of impoverished workers from the countryside has begun drying up, as increasing numbers consider it not worthwhile to migrate from their villages. Western multinationals have devised "corporate codes of conduct" setting a floor for labour standards and, under pressure from the international anti-sweatshop movement, are seeking to enforce the codes in the Chinese factories that produce goods bearing their brands. The Chinese Federation of Trade Unions has mounted new efforts to establish union branches in foreign-run enterprises, and has begun organising enterprise-level trade-union elections in state-owned enterprises.

These and the several other important developments, which will be examined in this paper are still just emerging. Tracking them helps us see what may lie ahead in the coming decade in Chinese labour relations. 